\title{
Family history of hypertension is associated with exaggerated cardiovascular reactivity to mental, but not to physical test
}

\author{
Ikhlas M. Jenie, ${ }^{1}$ Noriah M. Noor ${ }^{2}$ \\ ${ }^{1}$ Department of Physiology, Faculty of Medicine, University of Muhammadiyah Yogyakarta, Jakarta, Indonesia \\ ${ }^{2}$ Department of Basic Medical Sciences, Kulliyyah of Pharmacy, International Islamic University Malaysia
}

\begin{abstract}
Abstrak
Tujuan Membandingkan reaktivitas kardiovaskular terhadap tes mental dan fisik antara subjek normotensif dengan riwayat keluarga hipertensi dan subjek normotensif tanpa riwayat keluarga hipertensi.

Metode Mahasiswa normotensif dengan $(n=40)$ dan tanpa $(n=40)$ orangtua hipertensi melakukan tes aritmatika dan cold pressor. Kedua tes tersebut terdiri dari fase istirahat pra-tes, fase tes, dan fase istirahat pascates. Parameter kardiovaskular diukur pada tiap fase dengan menggunakan alat pengukur tekanan darah osilometrik otomatis. Data di analisis dengan tes t atau Mann-Whittney. Reaktivitas kardiovaskular diketahui berdasarkan selisih nilai fase tes dengan fase pra-tes.

Hasil Kedua kelompok tidak berbeda bemakna dalam usia, indeks masa tubuh, kadar gula darah puasa, dan kadar kreatinin plasma. Subjek normotensif dengan orangtua hipertensi menunjukkan tekanan darah sistolik istirahat

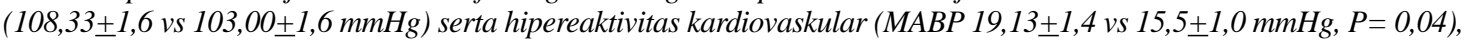
yang lebih tinggi secara bermakna terhadap tes mental namun tidak terhadap tes fisik (MABP 24,26+1,7 vs 21,74+1,7 $\mathrm{mmHg}$ ) dibandingkan dengan subjek normottensif tanpa orangtua hipertensi.

Kesimpulan Subjek normotensi dengan riwayat keluarga hipertensi mempunyai hipereaktifitas kardiovaskular terhadap tes mental namun tidak terhadap tes fisik dibandingkan dengan subjek normotensi tanpa riwayat keluarga hipertensi. Akan tetapi, belum jelas apakah riwayat keluarga hipertensi atau tekanan darah sistolik istirahat yang berhubungan dengan hipereaktifitas kardiovaskular terhadap tes mental. (Med J Indones 2010; 19:118-23)
\end{abstract}

\begin{abstract}
Aim To investigate whether normotensive young adults with family history of hypertension demonstrate exaggerated cardiovascular responses to both mental and physical stimuli as compared to normotensive young adults without family history of hypertension.

Methods Normotensive undergraduate students of normotensive parents $(\mathrm{n}=40)$ and of hypertensive father/ mother/ both $(n=40)$, aged $20-30$ years, performed serial subtraction test in a sitting position for three minutes. After taking a rest, subjects performed cold pressor test in ninety seconds. In each test, blood pressure and pulse rate were recorded in pre-test, during test, and post-test using an automated oscillometric device. Changes score rather than absolute scores were analyzed using independent t-test or Mann-Whitney.

Results There were no significantly differences in age, body mass index, fasting blood sugar, and plasma creatinine between the two groups. Normotensives of hypertensive parents had significantly higher office systolic blood pressure $(108.33 \pm 1.6 \mathrm{vs} 103.00 \pm 1.6 \mathrm{mmHg})$ and delta change score of cardiovascular reactivity to serial subtraction test (MABP $19.13+1.4$ vs $15.5 \pm 1.0 \mathrm{mmHg}, \mathrm{P}=0.04$ ), but not to cold pressor test (MABP $24.26+1.7 \mathrm{vs} 21.74+1.7 \mathrm{mmHg}$ ) than those of normotensive parents.

Conclusion Normotensive young adults with family history of hypertension demonstrated exaggerated cardiovascular reactivity to mental test but not to physical test. As compared to normotensive young adults without family history of hypertension However, this familial difference in cardiovascular reactivity to mental test is confused with office blood pressure. (Med J Indones 2010; 19:118-23)
\end{abstract}

Key words: cardiovascular reactivity, cold pressor test, mental arithmetic test, of hypertension

Although still not popular in clinical setting, cardiovascular reactivity (CVR) can be used as a non-invasive method to identify pre-clinical state of cardiovascular disease, i.e the pathogenic changes in cardiovascular structure and function that if continued will later manifest as cardiovascular disease, such as hypertension, myocardial infarct, and stroke. ${ }^{1}$ Thus, subjects who have exaggerated CVR as well Correspondence email to: ikhlasjenie@yahoo.co.uk as family history of hypertension are in high risk to develop cardiovascular disease. ${ }^{2}$ Numerous studies had investigated whether normotensive subjects with family history of hypertension have exaggerated CVR. However, those studies found conflicting results..$^{3-4}$ The controversial finding may be caused by several factors, such as the use of wide range of laboratory stimuli. ${ }^{4}$ This study aimed to investigate whether normotensive young 
adults with family history of hypertension demonstrate heightened cardiovascular responses to both mental and physical stimuli as compared to normotensive young adults without family history of hypertension.

\section{METHODS}

\section{Participants}

Participants were 80 undergraduate students of International Islamic University of Malaysia, Kuantan Campus. The inclusion criteria included subjects between 20-30 years old with systolic blood pressure (SBP) $<140 \mathrm{mmHg}$ and diastolic blood pressure (DBP) $<90 \mathrm{mmHg} .{ }^{5}$ The exclusion criteria were based on a self-reported questionnaire, anthropometric, and biochemistry measures. Based on a self-reported questionnaire, they were not having cardiovascular diseases, renal diseases, diabetes mellitus, psychiatric disorders, any medication affecting the cardiovascular system and not a smoker. By anthropometric measure, participants' body mass index was $\leq 27.3 \mathrm{~kg} / \mathrm{m}^{2}$ for female participants or $\leq 27.8 \mathrm{~kg} / \mathrm{m}^{2}$ for male participants. By biochemistry measures, participants' fasting blood sugar was $<6.1 \mathrm{mmol} / \mathrm{L}$ and plasma creatinine was $<133 \mathrm{mmol} / \mathrm{L}$.

\section{Family history of hypertension}

Participants were divided into two groups based on having or not family history of hypetension $(\mathrm{FHoH})$, based on a self-reported questionnaire. Criteria for having $\mathrm{FHoH}$ were based on parental history of hypertension, in which either her/ his father or mother or both had one of the following criteria: a) high blood pressure (SBP $>140 \mathrm{mmHg}$ or DBP $>90 \mathrm{mmHg}$ ), b) being diagnosed as hypertension, and c) being on medication for hypertension. Subjects were considered not having $\mathrm{FHoH}$ if her/ his father and mother did not have all the above criteria.

\section{Informed consent}

The participants were given explanation on the purpose of the study, the laboratory tests required to do, the inconvenient consequences that might occur, and the data confidentiality. After the explanation, if the participants agreed to take part in this study, they were required to give their consent. The Ethical Committee of International Islamic University Malaysia, Kuantan Campus had approved the study protocol.

\section{Cardiovascular (CV) parameters}

\section{Blood pressure}

Office SBP and DBP were measured by using mercury column sphygmomanometer (W.A. Baum. Co. Inc., New York, USA) based on Korotkoff sounds, in a sitting position after taking a rest at least for five minutes. ${ }^{6}$ During the test, SBP and DBP was measured using a non-invasive, automatic vital sign monitor device TM2551 P (A\& D Co. Ltd., Tokyo, Japan), from the brachial artery of the participants' dominant hand. The automatic vital sign monitor device TM-2551 P measures blood pressure by using oscillometric method, by which the blood pressure is derived from the oscillation of the pressure wave transmitted from peripheral artery during the cardiac cycle. ${ }^{7}$ Blood pressure reading of the automatic, non-invasive, oscillometric method was generally in a good agreement with that of the invasive, intra-arterial method ${ }^{6}$ and to remove observer bias.

\section{Pulse rate}

Pulserate(PR)rather than heart rate response was measured using a non-invasive, automatic vital sign monitor device TM-2551 P (A \& D Co. Ltd., Tokyo, Japan). ${ }^{8}$

\section{Pulse pressure}

Pulse pressure (PP) was calculated by subtracting SBP with DBP $(\mathrm{PP}=\mathrm{SBP}-\mathrm{DBP}){ }^{8}$

\section{Mean arterial blood pressure}

Mean arterial blood pressure (MABP) was calculated by the following formula: $\mathrm{MABP}=\mathrm{DBP}+(\mathrm{PP} / 3){ }^{8}$

\section{Rate pressure product}

Rate pressure product (RPP) was calculated by using formula: $\mathrm{RPP}=(\mathrm{SBP} \times \mathrm{PR}) / 100 .^{8}$

\section{Laboratory tests}

The laboratory tests consisted of mental arithmetic test and cold pressor test, which done in the order. Each test consisted of pre test, test, and post test. ${ }^{9}$ Before the test, the participants must restrain from eating, drinking coffee and exercising at least one hour before the laboratory session.

\section{Mental arithmetic test (MAT)}

In pre-test, participant took a rest in a sitting position for at least five minutes. At the end of this period, CV 
parameters were measured for at least three times. The two closest measurements were being averaged. During test, participant performed serial-subtraction test by subtracting seven continuously from the number 99 in the first thirty seconds, 300 in the proceeding one minute, and 2816 for the last one and half minutes in a sitting position. The participant had to calculate as quickly and accurately as possible (being harassed by the observer) and stated loudly the answers. If a wrong answer was given, she/ he had to repeat from the last right answer. Cardiovascular parameters were measured at the twentieth seconds of the $2^{\text {nd }}$ minutes. After completing the measurement, the participant ended the calculation. The total duration of the test was 3 minutes. In post-test, the participant took a rest in a sitting position for another $1 \frac{1}{2}$ half minutes. At the end of this, $\mathrm{CV}$ parameters were measured for at least three times. The two closest measurements were being averaged.

\section{Cold Pressor Test (CPT)}

The pre test and post test of CPT were similar with MAT. During test, the participant performed hand immersion test by immersing her/ his left hand up to the wrist into the $5^{\circ} \mathrm{C}$ iced-water placed in an icebox. Cardiovascular parameters were measured at the $5^{\text {th }}$ seconds. After completing the measurement, the hand was dried with a dry-towel. The total duration of the test period was $1 \frac{1}{2}$ minutes.

\section{Data reduction}

A delta change score of cardiovascular reactivity (CVR) was calculated by subtracting the $\mathrm{CV}$ parameters measured in the pre-test from the $\mathrm{CV}$ parameters measured during the test. A delta change score of cardiovascular recovery (CVRec) was calculated by subtracting the $\mathrm{CV}$ parameters measured in the pretest from the CV parameters measured in the post-test. ${ }^{9}$ Delta change score was used rather than absolute value in order to control the baseline level. ${ }^{9}$ Moreover, delta change score yields reliable measures of blood pressure and heart rate reactivity to laboratory stimulus.

\section{Data handling and analysis}

Microsoft Office Excel 2003 was used for data entry and reduction. Statistical Package for Social Sciences version 14.0 (SPSS Inc., Chicago, USA) was used for data summarize and analysis. Normality of data was tested by one sample Kolmogorov-Smirnov test. Mean \pm standard error of the mean (SEM) or median with inter-quartile range was used to summarize the data that normally or not normally distributed, respectively. To determine whether any differences of CVR and CVRec existed between the group with and without $\mathrm{FHoH}$, independent t-test or Mann-Whitney $\mathrm{U}$ test was performed for data that normally or not normally distributed, respectively. $p$ value $<0.05$ was considered as the statistical significance level.

\section{RESULTS}

\section{Characteristics of subjects}

Eighty subjects who met the inclusion and exclusion criteria joined this study. They were students from International Islamic University Malaysia, Kuantan Campus. All subjects were Malay, except 1 male and 2 female subjects who were Indian. We had 40 subjects without $\mathrm{FHoH}$ and another 40 subjects with $\mathrm{FHoH}$, which comprises of 17 subjects with hypertensive father, 15 subjects with hypertensive mother, and 8 subjects with both hypertensive father and mother. Gender was distributed equally: 20 female and 20 male subjects in each group, thus making the gender ratio $1: 1$ in each group. There were no significant differences in age, body mass index, fasting blood sugar, and plasma creatinine between normotensive young adults with and without FHoH (Table 1).

Table 1. Characteristics of subjects stratified by family history of hypertension

\begin{tabular}{lcc}
\hline \multicolumn{1}{c}{ Characteristics } & Without $\mathrm{FHoH}^{\mathrm{a}}$ & ${\text { With } \mathrm{FHoH}^{\mathrm{a}}}^{\mathrm{c}}$ \\
\hline Age (years) & 22 & 22 \\
& $(21.5-23)^{\mathrm{b}}$ & $(21-22)^{\mathrm{b}}$ \\
BMI $\left(\mathrm{kg} / \mathrm{m}^{2}\right)$ & $21.19 \pm 0.4$ & $21.59 \pm 0.4$ \\
FBS $(\mathrm{mmol} / \mathrm{L})$ & $4.43 \pm 0.05$ & $4.46 \pm 0.06$ \\
Plasma creatinine $(\mathrm{mmol} / \mathrm{L})$ & $80.55 \pm 2.7$ & $84.65 \pm 2.7$ \\
\hline
\end{tabular}

Note. $\mathrm{FHoH}=$ family history of hypertension; $\mathrm{BMI}=$ body mass index; FBS = fasting blood sugar. Data are summarized as mean \pm standard error of the mean (SEM), except for the data that are not normally distributed.

${ }^{a} \mathrm{~N}=40$ subjects. ${ }^{\mathrm{b}}$ Median (lower quartile - upper quartile) for data that are not normally distributed.

\section{Office blood pressure}

Normotensive young adults with FHoH had significantly higher office SBP than normotensive young adults without FHoH $(t=-2.34, p=0.02)$. However, normotensive young adults with and without $\mathrm{FHoH}$ did not differ significantly in office DBP (Table 2). 
Table 2. Office blood pressure stratified by family history of hypertension

\begin{tabular}{lcc}
\hline Office blood pressure & Without $\mathrm{FHoH}^{\mathrm{a}}$ & With $\mathrm{FHoH}^{\mathrm{a}}$ \\
\hline SBP $(\mathrm{mmHg})$ & $103 \pm 1.6$ & $108.33 \pm 1.6^{*}$ \\
DBP $(\mathrm{mmHg})$ & 60 & 67.5 \\
& $(56.5-70)^{\mathrm{b}}$ & $(60-70)^{\mathrm{b}}$ \\
\hline
\end{tabular}

Note. $\mathrm{FHoH}=$ family history of hypertension; $\mathrm{SBP}=$ systolic blood pressure; DBP $=$ Diastolic blood pressure. Data are summarized as mean \pm standard error of the mean (SEM), except for the data that are not normally distributed.

${ }^{a} \mathrm{~N}=40$ subjects. ${ }^{\mathrm{b}}$ Median (lower quartile - upper quartile) for data that are not normally distributed.

$* \mathrm{p}<0.05$ vs. control group.

\section{Cardiovascular reactivity to MAT}

This study found that normotensive young adults with FHoH exerted greater CVR to MAT as compared to normotensive young adults without $\mathrm{FHoH}$. Normotensive young adults with $\mathrm{FHoH}$ showed greater $\operatorname{DBP}(Z=-2.05, p=0.05), \operatorname{MABP}(t=-2.04, p=0.04)$ and RPP reactivity $(t=-2.06, p=0.04)$ to MAT than those without $\mathrm{FHoH}$. However, both groups did not differ significantly in SBP, PR, and PP reactivity to MAT (Table 3). In terms of CVRec from MAT, both groups did not differ significantly.

Table 3. Delta change score of cardiovascular reactivity to mental arithmetic test stratified by family history of hypertension

\begin{tabular}{lcc}
\hline Cardiovascular reactivity & Without $\mathrm{FHoH}^{\mathrm{a}}$ & With $\mathrm{FHoH}^{\mathrm{a}}$ \\
\hline SBP $(\mathrm{mmHg})$ & $17.46 \pm 1.4$ & $20.7 \pm 1.6$ \\
DBP (mmHg) & 13.5 & 16.75 \\
& $(9.13-19.25)^{\mathrm{b}}$ & $(11.63-24.38)^{\mathrm{b}}$ \\
PR (beats/min) & 8.75 & 9.25 \\
& $(5.5-13)^{\mathrm{b}}$ & $(4.5-14.88)^{\mathrm{b}}$ \\
PP (mmHg) & $2.94 \pm 1.4$ & $2.36 \pm 1.3$ \\
MABP (mmHg) & $15.5 \pm 1.0$ & $19.13 \pm 1.4^{*}$ \\
RPP (mmHg . beats/min) & $22.92 \pm 1.4$ & $29.84 \pm 2.8^{*}$ \\
\hline
\end{tabular}

Note. $\mathrm{FHoH}=$ family history of hypertension; $\mathrm{SBP}=$ systolic blood pressure; DBP $=$ diastolic blood pressure; $\mathrm{PR}=$ pulse rate; $\mathrm{PP}=$ pulse pressure; $\mathrm{MABP}=$ mean arterial blood pressure; $\mathrm{RPP}=$ rate pressure product. Data are summarized as mean \pm standard error of the mean (SEM), except for the data that are not normally distributed.

a $\mathrm{N}=40$ subjects. $\mathrm{b}$ Median (lower quartile - upper quartile) for data that are not normally distributed.

$* \mathrm{p}<0.05$ vs. control group.

\section{Cardiovascular reactivity to CPT}

There were no significant differences in SBP, DBP, $\mathrm{PR}$, PP, MABP, and RPP reactivity to CPT between normotensive young adults with and without $\mathrm{FHoH}$ (Table 4). Both groups did not differ significantly in terms of CVRec from CPT.
Table 4. Delta change score of cardiovascular reactivity to cold pressor test stratified by family history of hypertension

\begin{tabular}{lcc}
\hline Cardiovascular reactivity & Without $\mathrm{FHoH}^{\mathrm{a}}$ & With $\mathrm{FHoH}^{\mathrm{a}}$ \\
\hline SBP $(\mathrm{mmHg})$ & $23.84 \pm 1.9$ & $26.68 \pm 1.8$ \\
DBP $(\mathrm{mmHg})$ & $20.69 \pm 1.8$ & $23.05 \pm 1.8$ \\
PR (beats/min) & 1.25 & 3.25 \\
& $(-4.75-6.25)^{\mathrm{b}}$ & $(-0.38-8.63)^{\mathrm{b}}$ \\
PP (mmHg) & 2.5 & 3.25 \\
& $(-1.25-5.88)^{\mathrm{b}}$ & $(-1.88-9.75)^{\mathrm{b}}$ \\
MABP (mmHg) & $21.74 \pm 1.8$ & $24.26 \pm 1.7$ \\
RPP (mmHg . beats/min) & $18.73 \pm 2.4$ & $24.80 \pm 1.8$ \\
\hline
\end{tabular}

Note. $\mathrm{FHoH}=$ family history of hypertension; $\mathrm{SBP}=$ systolic blood pressure; DBP $=$ diastolic blood pressure; $\mathrm{PR}=$ pulse rate; $\mathrm{PP}=$ pulse pressure; $\mathrm{MABP}=$ mean arterial blood pressure; $\mathrm{RPP}=$ rate pressure product. Data are summarized as mean \pm standard error of the mean (SEM), except for the data that are not normally distributed.

${ }^{a} \mathrm{~N}=40$ subjects. ${ }^{\mathrm{b}}$ Median (lower quartile - upper quartile) for data that are not normally distributed.

\section{DISCUSSION}

This study found normotensive young adults with FHoH have exaggerated CV reactivity to MAT but not CPT. These results are in accordance to previous studies. ${ }^{10-12}$ Based on the reactivity hypotheses ${ }^{13}$, there are at least three levels that might account for individual differences in cardiovascular responses, namely cortical (such as temperament), subcortical (autonomic outflow and endocrine regulation from the brain stem and hypothalamus), and peripheral (such as differences in sensitivity of adrenergic receptors in blood vessels). MAT and CPT differ in the mechanism to stimulate $\mathrm{CV}$ response. MAT is an active task; it is a cardiac stimulator because the mental load promotes a rise in plasma epinephrine and elicits a rise in blood pressurep through an increase in cardiac output (CO). ${ }^{14-15}$ The reason of $\mathrm{CO}$ increases in response to an active task had been explained by Obrist, in nearly 30 years ago. ${ }^{9}$ Meanwhile, CPT is a passive coping task; it is a vascular stimulator since it causes a rise in plasma norepinephrine ${ }^{8}$ and promotes a pressor response through an increase in total peripheral resistance. ${ }^{16}$ Therefore, MAT and CPT can be used to assess either cortical, subcortical, or peripheral tissues differences of the cardiovascular responses in the background of the influence of familial history of hypertension.

The results of the study seem to support a view that normotensive young adults with $\mathrm{FHoH}$ already have structural changes in $\mathrm{CV}$ system., ${ }^{17}$ Among $\mathrm{CV}$ parameters measured in this study, exaggerated response in DBP and RPP reach borderline significant and significant difference, respectively. However, 
the exaggeration of DBP in response to MAT among normotensive young adults with $\mathrm{FHoH}$ is not in line with the fact that MAT is a cardiac stimulator. If $\mathrm{CO}$ increases, SBP should be affected first than DBP. Consequently, as Obrist had explained, an inappropriate increased $\mathrm{CO}$ will disturb vascular autoregulation. ${ }^{9}$ Actually, autonomic or sympathoadrenal dysfunction for long time had been suspected to contribute to the development of hypertension, although conflicting results were also still observed. ${ }^{18-19}$ Baroreflex dysfunction ${ }^{4}$ may contribute the disturbance of vascular autoregulation, serving as another explanation for the exaggerated DBP reactivity in normotensive young adults with family history of hypertension.

In this study, normotensive subjects with $\mathrm{FHoH}$ have significantly greater office SBP than the controls. Thus, it opens to debate whether FHoH or office SBP that correlates to exaggerated CV response to MAT. A line of evidences shows that normotensive offspring of hypertensive parents have slightly higher office ${ }^{20}$, home ${ }^{21}$, and 24 hour-SBP ${ }^{22}$ a s compared to normotensive offspring of normotensive parents. Recently, Flaa et al. ${ }^{23}$ has examined CVR in normotensive men, who were divided into different level office BP (low, normal, and high). They found that normotensive subjects with high level of office BP exerted greater $\mathrm{CV}$ reactivity to MAT, but not to CPT, as compared to normotensive subjects with lower level of office BP. What Flaa et al. have reported supports the possibility that office BP does contribute to the development of exaggerated CVR. It may provide additional explanatory variable to explain conflicting results in this area.

This study was not conducted to verify causal relationship between exaggeration of CVR to mental stressor/ stimulus and the development of hypertension. ${ }^{24}$ However, in the study of family history of hypertension, the question of having hypertensive or normotensive parents should be validated as there may be potential for misclassification which otherwise would obscure relationships of the status of $\mathrm{FHoH}$ and cardiovascular hypereactivity.

As conclusion, normotensive young adults with family history of hypertension had exaggerated cardiovascular reactivity to mental but not to physical test. However, we are not sure whether familial history of hypertension or office blood pressure that relates to cardiovascular hypereactivity.

\section{REFERENCES}

1. Treiber FA, Kamarck T, Schneiderman N, Sheffield D, Kapuku G, Taylor T. Cardiovascular reactivity and development of preclinical and clinical disease state. Psychosom Med. 2003;65(1):46-62.

2. Linden W, Gerin W, Davidson K. Cardiovascular reactivity: Status quo and a research agenda for the new millennium. Psychosom Med. 2003;65(1):5-8.

3. Pierce TW, Grim RD, King JS. Cardiovascular reactivity and family history of hypertension: A meta analysis. Psychophysiology. 2005;42:125-31.

4. Kamarck TW, Lovallo WR. Cardiovascular reactivity to psychological challenge: conceptual and measurement considerations. Psychosom Med. 2003;65(1):9-21.

5. Chobanian AV, Bakris GL, Henry R, Cushman WC, Green LA, Izzo JL Jr, et al. Seventh report of the Joint National Committee on Prevention, Detection, Evaluation, and Treatment of High Blood Pressure. Hypertension. 2003;42(6):1206-52.

6. Pickering TG, Hall J, Appel L, Falkner B, Graves J, Hill MN $\mathrm{RN}$, et al.. Recommendations for blood pressure measurement in humans and experimental animals part 1: Blood pressure measurement in humans: A statement for professionals from the subcommittee of professional and public education of the American Heart Association Council on High Blood Pressure Research: American Heart Association scientific statement. Hypertension. 2005; 45(1):142-61.

7. Van Montfrans GA. Oscillometric blood pressure measurement: Progress problems. Blood Press Monitoring. 2001; 6:287-90

8. Levick JR. An introduction to cardiovascular physiology. ( $3^{\text {rd }}$ edn.). London: Arnold; 2000.

9. Gerin W, Pickering TG, Glynn L, Christenfeld N, Schwartz A, Caroll D, et al. An historical context for behavioral models of hypertension. J of Psychosom Res. 2000; 48:369-77.

10. Schneider GM, Jacobs DW, Gevirtz RN, O'Connor DT. Cardiovascular hemodynamic response to repeated mental stress in normotensive subjects at genetic risk of hypertension: Evidence of enhanced reactivity, blunted adaptation, and delayed recovery. J of Hum Hypertension. 2003;17(12):829-40.

11. Li R, Alpert B, Walker S, Barnard M. Vascular reactivity associated with parental hypertension: A longitudinal study of students from third grade to eight grade [abstract]. Circulation. 2005;III(14):231.

12. Frazer NL, Larkin KT, Goodie JL. Do behavioral response mediate or moderate the relation between cardiovascular reactivity to stress and parental history of hypertension? Health Psy. 2002;21:244-53.

13. Lovallo WR, Gerin W. Psychophysiological reactivity: Mechanism and pathways to cardiovascular disease. Psychosom Med. 2003;65:36-45.

14. Bedi M, Varshney VP, Babbar R. Role of cardiovascular reactivity to mental stress in predicting future hypertension. Clin \& Exp Hypertension. 2000; 22(1):1-22.

15. Hjemdahl P. Cardiovascular system and stress. In G. Fink. (ed.). Encyclopedia of stress. (Vol. 1: A-D). London: Academic Press; 2000. 
16. Sarabi M, Lind L. Mental stress opposes endotheliumdependent vasodilation in young healthy individuals. Vasc Med. 2001;6:3-7.

17. Neutel JM, Smith DH. Hypertension control: Multifactorial contributions. Am J of Hypertension. 1999;12(12 Pt 1-2):164S9S.

18. Maver J, Strucl M, Accetto R. Activity of autonomic nervous system and microvascular reactivity in normotensive subjects with a familial predisposition to hypertension. J of Hypertension. 2000;18(Suppl 2):S81.

19. Lambert EA, Schlaich MP. Reduced sympathoneural responses to the cold pressor test in essential hypertension and in those genetically predisposed to hypertension: No support for the "pressor reactor" hypothesis of hypertension development. Am J of Hypertension. 2004;17(10):863-8.

20. Ravogli A, Trazzi S, Villani A, Mutti E, Cuspidi C, Sampieri L. Early twenty-four-hour blood pressure elevation in normotensive subjects with parental hypertension [abstract]. Hypertension. 1990;16(5):491-7.
21. Kawabe H, Saito I, Nagano S, Saruta T. Relation of home blood pressure to body weight in young normotensive men with or without family history of hypertension. Am J of Hypertension. 1994;7:498-502.

22. Parati G, Ravogli A, Trazzi S, Villani A, Mutti E, Gropelli A, et al. Early twenty-four-hour blood pressure elevation in subjects with parental hypertension. J of Hypertension. 1989; 7(Suppl. 6):S64-5.

23. Flaa A, Mundal H, Eide I, Kjeldsen S, Rostrup $M$. Sympathetic activity and cardiovascular risk factors in young men in the low, normal, and high blood pressure ranges. Hypertension. 2006;47(3):396-402.

24. Schwartz AR, Gerin W, Davidson KW, Pickering TG, Brosschot JF, Thayer JF, et al. Toward a causal model of cardiovascular responses to stress and the development of cardiovascular disease. Psychosom Med. 2003;65(1):2235 . 
